\title{
Legal Culture of restorative Justice in Juvenile Criminal Justice System in Indonesia
}

\author{
Nur Rochaeti \\ Universitas Diponegoro \\ Semarang, Indonesia \\ Iyenk283@yahoo.co.id
}

\begin{abstract}
Children have different rights specifically with the rights of an adult human. Based on Act No.11 of 2012 on Juvenile Criminal Justice System describes the judicial proceedings against juvenile in conflict with the law. This study aims to address two issues: firstly why it is restorative justice be required in the juvenile justice system, and secondly how the implementation of restorative justice juvenile justice system in Indonesia. The research location in Medan and Bali. Using the method of approach to socio-legal research. The purpose of this study was to find a model in handling juvenile is against the law in Indonesia. The results of this research, restorative justice is required to minimize the stigma as well as the best interests of the child. Implementation of restorative justice in the juvenile justice system in Indonesia is also one of them attempts to optimize the living law in Indonesia.
\end{abstract}

Keyword: legal culture, restorative justice, juvenile criminal justice system

\section{INTRODUCTION}

The rights of children currently, especially regarding the protection of children in the juvenile justice system has not been sufficiently able to provide better conditions in terms of getting rid of the bad condition of the child.

The judicial process causes adverse psychological effects for children. They will be under pressure and stigmatization during the judicial process, and based on that all activities undertaken in the context of whether the juvenile justice by the police, prosecutors, judges or other officials, must be based on the principle is for the welfare of the child and the child's interests.

The limitations of the use of criminal law in combating crime in general and children in delinquency specifically, that only combat the symptoms and do not touch the root surface is often called "kurieren am symptoms" on one side, and on the other hand still think rare exploring conceptual concrete criminal policy of non - criminal.

Under these conditions, it is required restorative justice as a form of delinquency prevention more attention to the special needs of children, and in an effort to achieve restorative justice. Restorative justice is a theory that emphasizes the loss and restore broken relationships caused or incurred by a criminal act. Recover losses and this relationship will be achieved by cooperative processes that include all stakeholders (interested) [1].

\section{RESULT AND DISCUSSION}

According to the model of restorative, delinquency behavior is behavior that is detrimental to the victim and the community. Restorative justice is not punitive. Its main objective to repair of the wounds caused his actions, and conciliation and reconciliation among victims, offenders, and communities. Restorative Justice also intends to restore the well-being of society through the child's behavior for the responsibility for his behavior. Victims are given the opportunity to participate in the process. According to Braithwaite express ways as it gave birth to feelings of shame and personal and family responsibility for the mistake actions of offender to repaired.

The real goal of restorative justice is to restore harmony between victims and offender. The offender, must be responsibility, dealing with shame, and regain their dignity. This idea has grown rapidly, with major new conceptual developments, namely the incorporation of the role of the community.

Most restorative justice advocates agree that the process involves five basic principles:

a. Crime is not just from the criminal law violations and irregularities against government power.

b. Crime cause disruption in the three-dimensional relationship between the victim, the community, and the offender.

c. Because the crime to harm the victim and the community, the main goal should repair the damage and heal the victims and society.

d. Victims, communities, and offenders must all participate in determining the response to crime; government should hand over authority over the process.

e. Disposition of cases should be based primarily on the needs of the victim is not solely on the needs of the offenders or error, danger, or history [2].

John Braithwaite argued, that Restorative Justice aimed at restoring harmony or balance when the law has been enforced [3]. Restoring harmony / balance is an sich is not enough, therefore "restore balance" can only realize the idea of justice diteima as if "balance" morally between offenders and victims that existed previously are appropriate balance.

In restorative justice, the role of the community is very important, since understanding to the implementation of the judicial system. Even restorative justice will fail if the 
community does not participate in the implementation of the process.

Howard Zehr opinion of restorative justice derived from the values of the indigenous people who have been there for decades, namely in restorative justice see a criminal case as:

"Viewed through a restorative justice lens," crime is a violation of people and relationships. It creates obligations to the make things right. Justice involves the victim, the Offender, and the community in a search for solutions roomates promote repair, reconciliation, and reassurance. " [4]

In a restorative justice approach, the main victims upon the occurrence of a crime is not a country, as in the criminal justice system that now exists, but it is the individual.

The protection of juvenile against the law has been set up in several international legal instruments include the UN Standard Minimum Rules on the Administration of Justice for Juvenile ("Beijing Rules") by the United Nations Assembly Resolution No. 43/33 November 29, 1985 and the UN Guidelines order Crime Prevention Centre ("Riyadh Gidelines") authorized and declared in the UN General Assembly Resolution No. 45/112 December 14, 1990, with the assertion that the UN resolution is the minimum standards for the protection of juvenile from all forms of deprivation of liberty, which is based on human rights and prevent the child from the side effects of all forms of detention in order to achieve the integration of children into society. In addition, the Convention on the Rights of the Child (Convention on the Rights of the Child) are acting as international law began on 2 September 1990, which saw the need to perform the steps of systematic and comprehensive to provide protection to children who are in conflict with the law.

In Indonesia based on The Act No. 11 of 2012 on The Juvenile Criminal Justice System regulate the entire process of settling disputes concerning Juvenile against the law began the investigation phase to prosecution, judicial proceedings and punishmant.

\section{CONCLUSION}

Restorative justice is required to replace Retributive Justice. Crime in restorative justice is not seen as a violation of the state's interest, but is considered infringement of a person by another person. In this case the restitution is a means of improvement of the parties and the reconciliation and restoration is the ultimate goal. The victims and offender of criminal acts are recognized, both in the problems and in the settlement. The rights and needs of victims are recognized; criminals are offender to take responsibility.

Implementation restorative justice juvenile criminal justice system Conditions in Medan is a community pluralistic society in a variety of ethnic, namely Batak, India, China, Java, each of which has its own characteristics and has social cohesion in the group, so it is a challenge to optimize the implementation of restorative justice in the juvenile criminal justice system prioritizing efforts diversion and restorative justice. Different condition in Villages Kesiman, Villages Pagringsingan, Tenganan Bali, have procedure to handling all problem in community by common law, namely awig-awig and pakraman.

Mechanism legal abuses settlement through Paruman do with the principle of consultation and consensus (paras paros gilik seguluk) to stick to the principles of harmony, decency and harmony, taking into account all aspects concerning the interests of the perpetrator, the victim, and society as a whole.

\section{REFERENCES}

[1] Muladi, Capita Selecta Criminal Law, Semarang: Publisher Agency Diponegoro University, 1995

[2] Hagan, Frank E., Criminology Today, Amerika Latin, Wadsworth Group, Thomson Learning, 2002, p. 184

[3] Braithwite, John, Restorative Justice : Assessing an Immodest Theory and a Pessimistic Theory Draft to be summited to Crime and Justice : Review of Research, University of Chicago, Press.

[4] Zehr, Howard, Changing Lenses : New Focus for Crime and Justice, Scottdale, Pennsylvania, 1990. 